\title{
Oral manifestation of Goltz-Gorlin syndrome in a young girl
}

\author{
M Callea ${ }^{1 *}$, I Yavuz ${ }^{2}$, L Deroma ${ }^{3}$, M Montanari $^{4}$, G Clarich $^{1}$, M Maglione $^{5}$, E Albertini ${ }^{6}$, L Garavelli $^{7}$ \\ From 5th International Conference on Ectodermal Dysplasia (ED2012) \\ Erlangen, Germany. 1-3 June 2012
}

\section{Introduction}

Focal dermal hypoplasia (Goltz-Gorlin syndrome) is a multi-system disorder characterized by involvement of skin, skeletal system, eyes and face. It is caused by lossof-function mutations in the PORCN gene. We report the case of a young female, focusing on the dental features.

\section{Aim}

To describe the oral manifestation of a rare disorder that resembles ectodermal dysplasia (ED).

\section{Case report}

Clinical, radiological and genetic findings revealed common features of Goltz-Gorlin syndrome and pure ED. Oro-dental characteristics of the patient mostly corresponded to those described in the literature. However, previously unreported oro-dental findings such as taurodontism, peg-shaped teeth and microdontia are considered unusual for Goltz-Gorlin syndrome, but similar to the dental features of hypohidrotic ED. Clinical characterization of the patient by a multidisciplinary approach is described and a comprehensive review of the literature is presented.

\footnotetext{
Author details

'Department of Maxillo-Facial Surgery and Paediatric Dentistry, Institute for Maternal and Child Health, Trieste, Italy. ${ }^{2}$ Dicle University, Diyarbakır, Turkey. ${ }^{3}$ University Hospital Santa Maria della Misericordia, Udine, Italy. ${ }^{4}$ University of Bologna, Italy. ${ }^{5}$ University of Trieste, Italy. ${ }^{6}$ University of Ferrara, Italy. ${ }^{7}$ S. Maria Nuova Hospital, Reggio Emilia, Italy.
}

Published: 25 May 2012

'Department of Maxillo-Facial Surgery and Paediatric Dentistry, Institute for Maternal and Child Health, Trieste, Italy

Full list of author information is available at the end of the article
doi:10.1186/1746-160X-8-S1-P8

Cite this article as: Callea et al: Oral manifestation of Goltz-Gorlin syndrome in a young girl. Head \& Face Medicine 2012 8(Suppl 1):P8.
Submit your next manuscript to BioMed Central and take full advantage of:

- Convenient online submission

- Thorough peer review

- No space constraints or color figure charges

- Immediate publication on acceptance

- Inclusion in PubMed, CAS, Scopus and Google Scholar

- Research which is freely available for redistribution

Submit your manuscript at www.biomedcentral.com/submit
C Bïomed Central 